\title{
Living Side by Side in an Individualized Society: Home, Place, and Social Relations in Late Modern Swedish-Language Picturebooks
}

\author{
Kristina Hermansson
}

One of the most common narrative patterns in children's literature begins with the protagonist leaving home on an adventure and ends with his or her return home (Nikolajeva 2004; Nodelman 2008). Home is associated with safety and feelings of security, compared to the more dramatic but also potentially dangerous ("away"). Home is situated in a familiar, private space in contrast to the public or semi-public spaces in which various adventures take place. In this chapter, I explore the written and visual constructions of characters and social relations in relation to place, focusing on the above-mentioned narrative pattern in a selection of contemporary Swedish-language picturebooks published in Sweden and Finland between 2006 and 2014. What characterizes the interplay between place and social relations in these works? How does the presentation of place

K. Hermansson ( $\bowtie)$

University of Gothenburg, Gothenburg, Sweden

(C) The Author(s) 2020

K. Malmio, K. Kurikka (eds.), Contemporary Nordic Literature

and Spatiality, Geocriticism and Spatial Literary Studies, https://doi.org/10.1007/978-3-030-23353-2_4 
shape the presentation of characters and social relations, and vice versa? How is the basic home-away-home pattern negotiated and renegotiated?

Picturebooks from the 2000s tend to increasingly blur conventional boundaries between children and adults. Sandra Beckett claims that contemporary picturebooks "play an essential role in the crossover phenomenon" often dealing with "adult," dark, and painful themes, especially in Scandinavian countries (Beckett 2002, 2). Furthermore, these works also tend to mock conventional forms of children's narrative by using literary features such as polyfocalization, irony, and a complex interplay between visual and verbal aspects (Beckett 2002, 17). As I intend to demonstrate in the following, the selection of picturebooks analyzed in this chapter exploits and reshapes the basic home-adventure-home pattern.

My material consists of three Swedish-language picturebooks from the 2000s which examine aspects of living together side by side, though not in the same home or family. All three titles address the home and social relations, though from slightly different perspectives and in different ways. The specific titles examined are Milja och grannarna (Sandelin 2006; "Milja and the neighbors"), Sonja, Boris och tjuven (Lindström 2007; "Sonja, Boris, and the thief"), and Tilly som trodde att ... (Staaf 2014: "Tilly who thought that ...").

These works address questions that are dealt with by late modern cultural theory, such as individualism, social isolation, and the emphasis on security (Beck 1992; Bauman 2000; Brown 1995). The three titles investigate the possibilities of cohabitation in different places: a row of terraced houses, a campsite, and an apartment building and its surroundings. The characters and their social relations depicted are intertwined with written and visual spatial elements, though the spatial aspects of social relations are thematized even on the narrative level. The similarities in both themes and narrative structures in the current examples make this a productive literary corpus to examine from the point of view stated above. During the 2000 s and especially the last five years, there have been several picturebooks on the topic of neighbors, often focusing on various kinds of environments, living conditions and family constellations. ${ }^{1}$ This tendency should be set against the backdrop of an increasing strive for a more inclusive and socially engaged children's literature, dealing with social relations and diversity from different aspects and perspectives (Hermansson and Nordenstam 2017).

Milja och grannarna starts by depicting the protagonist's inner vision of what it ought to be like to live in a terraced house, in contrast to her own experience. The plot in "Sonja, Boris, and the thief" is set in a semi-public 
place, in a temporary community, while "Tilly who thought that ..." depicts people living in the same apartment building or in one case outside on the street. All together these books thematize the art of living together in the same place, side by side though not under the same roof or in the same family. By examining the presentation from a spatial point of view, I intend to shed light on how the presentations of place also shape the presentations of characters and social relations, and vice versa.

In the analysis, I will primarily draw on Doreen Massey's theories of space and place, especially her concept of throwntogetherness. According to Massey, space should be imagined as open, multiple as well as performative or challenging (Massey 2005). This concept is not unlike the established spatial theories of Henri Lefebvre (1991). While Lefebvre intends to expose the production of space in late capitalism on a universal basis, Massey instead focuses on particular processes, adding parameters other than class, such as gender and ethnicity (Massey 2005). With her concept of throwntogetherness, she aims to illuminate places as events, "the unavoidable challenge of negotiating a here-and-now (...) a negotiation which must take place within and between both human and nonhuman" (Massey 2005, 140). A place or, as in this case, a written and visual presentation of a place in a picturebook, is hence regarded as an event, a performance that takes place in a certain context. This means that although the plot and characters are set in certain places, the spatial presentation cannot be comprehended separately but only in relation to other parameters. Following Massey, I put no particular effort into differentiating "space" from "place," using both terms more or less synonymously. However, place is often used in a broader sense, while space or spatial instead functions in more abstract, analytical ways (Massey 2005, 185). Following both Lefebvre and Massey, space is not regarded as an empty vessel but as something people do based on specific discursive premises. A place has no inherent reality but, according to Lefebvre, is being produced and, adding Massey's reasoning on the subject, also reckoned in its specific manifestations in time and space (Lefebvre 1991). What makes Massey particularly relevant to my present aims is her emphasis on the connections between place and social relations: "Places pose in particular form the question of our living together" (Massey 2005, 151). Further, she focuses on various power relations and was among the first to apply intersectional perspectives (Rönnlund and Tollefsen 2016, 49). This is also in line with the aims and means of this chapter. 
When analyzing picturebooks, my current theoretical starting point entails regarding place as an iconotextual performance. The notion of iconotext was coined by Kristin Hallberg in 1982 and refers to the interplay between verbal and visual aspects (Hallberg 1982, 165). The main aim of my study is to examine how places and social relations are presented in writing as well as visually in the selected picturebooks. The starting point in spatial theory is intertwined with a desire to explore the presentation of social relations in order to enlighten both obstacles and opportunities in the imagination and in the organization of social relations in general. As Massey puts it: "The political corollary is that a genuine, thorough, spatialisation of social theory and political thinking can force into the imagination a fuller recognition of the simultaneous coexistence with others with their own trajectories and their own stories to tell" (Massey $2005,11)$.

\section{Broken Neighbors: A Shackled Community}

Milja och grannarna explores the theme of living side by side in a row of terraced houses in a Finnish or Nordic setting. The story is told from the viewpoint of Milja, a six-year-old girl who lives with her parents:

När Milja ska somna om kvällarna funderar hon ibland på hur det ser ut hemma hos grannarna. Hon skulle så gärna gå in till dem och titta, men hon får nöja sig med att se in genom fönstren i smyg. (Sandelin 2006, spread 3)

When Milja is about to fall asleep in the evenings, she sometimes ponders how things might look in the neighbor's houses. She would love to peep into their houses to see for herself, but she has to content herself with looking through the windows in disguise. (Trans. $\mathrm{KH}$ )

The spread visually presents Milja's gender-biased imaginations of her neighbors: Mr. Marudd is lifting weights, Miss Alopeus is watering her plants, and Jonas the librarian is reading a book about ghosts, dressed in black and portrayed as looking almost like a vampire. Behind the picture of Jonas situated in a gray thought balloon, there is a spider web further enhancing the supposed mysterious profile of the librarian.

The adult characters are generally presented as caricatures rather than individualized persons, everyone being annoyed at their neighbors' behavior. According to the narrator, the only one who Milja has visited from the outset is Miss Alopeus. However, by means of an omniscient narrator, the reader 
gains an insight into the homes and lives of all the characters. Miss Alopeus works in a perfume store. She uses her vacuum cleaner to block what she regards as disturbing noise from her neighbor, Jonas, a librarian who plays the saxophone. Mr. Marudd lives with his dog and is annoyed at both Alopeus and Jonas on account of the noise they produce. Jonas, on the other hand, is irritated by Marudd's early morning habits. The reader is informed of this by the narrator, focalizing different characters on different spreads, though first and foremost on Milja. The fact that Mr. Marudd is wearing a jumper with the text "Suomi" (Finland) and a print of the Finnish flag, contributes to presenting this spry, winter-loving character as well as accentuating the national setting.

When the neighbors meet outside their houses, they do not say hello to one another, even though they have been living side by side for several years. This fact, as it is presented by the narrator, is contrasted to Milja's ideal vision of what it would be like to live in a terraced house, with a shared flowerbed and all the neighbors taking turns shoveling snow and sometimes inviting one another for a cup of coffee or tea. On the spread visually depicting Milja's imaginary row of houses, the façade is white and red and the setting is full of green trees, flowers, and happy people. Even the cats seem content, looking at each other with a symbolic heart hovering above one of them. In contrast, the next spread visualizes how things really are, according to the narrator focalizing Milja. In this picture, the façade is gray, the trees have no leaves, and the people look unhappy and walk in different directions. They all seem isolated and the atmosphere conveyed is depressing.

After several spreads telling of the neighbors' trouble coping with one another's behavior, there is one spread depicting Miss Alopeus on a chilly winter's day as she walks to the shopping center. In the snowy background, Milja is sledding down a hill. On the right page it is shown how she slips on a patch of ice and falls, presented in simultaneous succession (Nikolajeva and Scott 2001, 139-40). The linear plot is depicted by four examples of Miss Alopeus in various positions, to be read as a sequence. The following spread contains ten separated visual scenes depicting the approach of Jonas, who also falls when trying to help his neighbor. Image number ten shows both of them lying on top of each other, with his feet on her head. While the visual presentation presents the fall in detail, the surrounding verbal text adds a background from Jonas's perspective, but also contains a bit of dialogue. For the first time, out in the street in a public space, the two neighbors say hello. But as Jonas tries to help Miss Alopeus to her feet, he slips on the same icy patch. The next spread presents Mr. Marudd 
on his way to the grocery store. He falls in exactly the same spot, though this is pictured in close-up, showing the three neighbors piled up on top of each other.

Marudd's dog informs Milja about what has happened, while she helps the injured neighbors get to hospital. Eventually they end up in the same room, unable to move. Trapped in one space, shackled to their beds, they are unable to avoid one another's characteristics and habits. This situation makes them even more irritated with one another. As Massey writes, "the chance of space may set us down next to the unexpected neighbor" (Massey 2005, 151). In this part of the book this chance is taken to the extreme, since neighbors, in denotative terms, are now situated not only in the same row of terraced houses under the same roof, but literally side by side. The only character joining this group of people voluntarily is Milja, the young protagonist who from the outset is presented as a curious person with a huge interest in her neighbors. However, when she offers neighbors pastries, the social tensions dissipate: "You are even closer neighbors now," she says ("Ni är ännu närmare grannar nu, säger hon") (Sandelin 2006, spread 21).

Happiness emerges in the room as the neighbors start eating, smiling at one another, and talking with each other. As Jonas, almost completely wrapped in $\mathrm{ABC}$ bandage, plays the saxophone, colorful flowers come out of the instrument in the picture.

On the last spread, the neighbors are portrayed in an almost utopian community, playing and barbecuing together in perfect harmony. Though, the terrace house in the background still looks like a prison, beige and grey with dark windows. Once again, sharing a meal is presented as an almost emblematic expression of a positively contested throwntogetherness, bridging individual differences and former conflicts as well as singular habitations. The neighbors are no longer shackled in the same room, with legs and arms in casts or socially or physically separated. They are presented outdoors in their intimate neighborhood, voluntarily sharing time and space with people they had not originally chosen to cohabit with but had tried to avoid. They have returned home, yet they are pictured at another much more colorful place than the gloomy one initially presented. Even the environmental setting is transformed. The final spread contains not only happy people having a barbecue, but also flowers, stars, and music. Milja has attained new knowledge of her neighbors, but the transformation presented is much more ample: it involves the social relations and thus, the entire community (Fig. 4.1). 


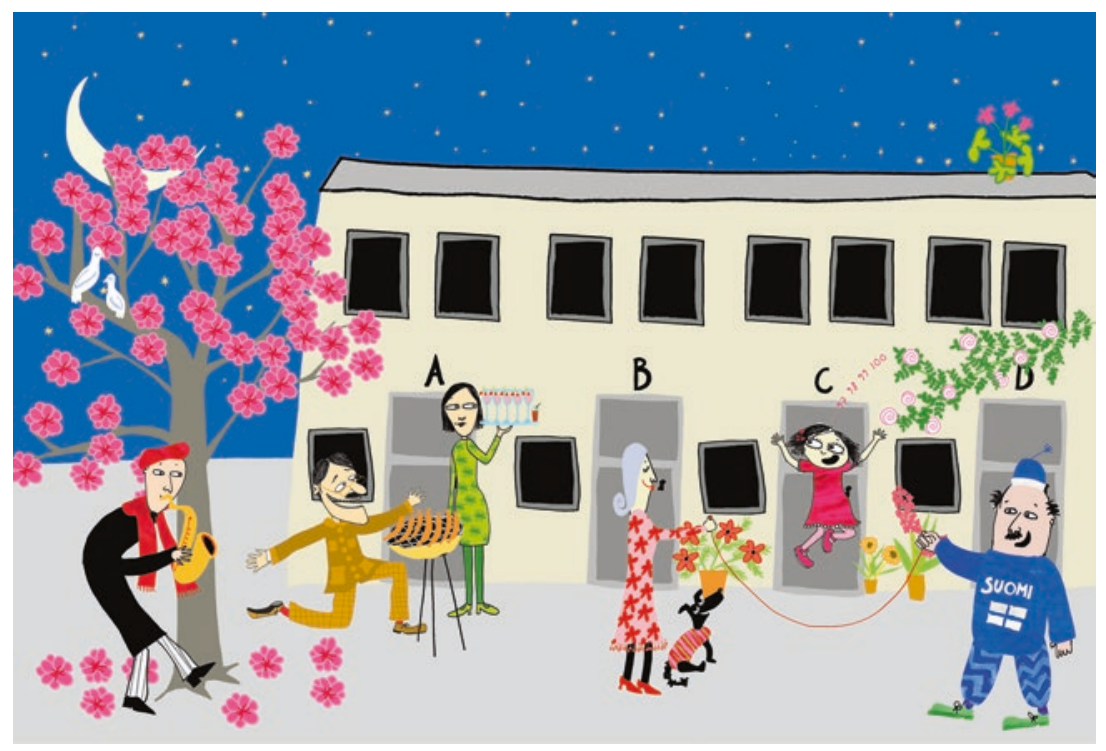

Fig. 4.1 Linda Bondestam's illustration in Milja och grannarna (2006), by Annika Sandelin and Linda Bondestam

\section{At the Campsite: Cohabitation and A Criminal Manhunt}

Recurring themes in the picturebooks of the prominent Swedish author and illustrator Eva Lindström are control and loss-be it a loss of friends, gloves, or even a forest. In Lindström's I skogen (2008; "In the forest"), these themes, specifically, an attempt to control the environment leading to its loss, are taken to extremes since the forest simply goes on vacation.

The themes of loss and the vain pursuit of control are intertwined with a significant aspect of Lindström's mode of visual expression: messiness. There is no central perspective in the visual presentations: people, animals, and things seem scattered in both sparse and cluttered environments, whether a forest or a hotdog stand. Using watercolor, gouache, and graphite, Lindström creates flat settings in which things happen simultaneously, like scenery or a visual palimpsest, adding layer on layer without a clear hierarchy. Humans and animals are mixed. According to Elina Druker, Lindström's picturebooks parody the detective genre by 
intertwining absurd subtexts (Druker 2011). Furthermore, according to Ulla Rhedin, they cast light on children's concrete way of thinking (Rhedin 2013).

Sonja, Boris och tjupen (Sonja, Boris, and the thief) is a twisted detective story in the form of a picturebook. The front cover shows a bold man wearing orange sweatpants and a yellow sweater and a woman with gray hair and a ballet-inspired outfit. Behind the human couple there is a tent, a small table, and a camping stove. There are also several trees in gray, blue, and purple. The landscape looks Nordic, despite the intense, artificial colors. The place, as the reader is soon informed, is a campsite inhabited by the human couple Sonja and Boris as well as various humanized animals wearing clothes. Björnen ("The Bear") is the owner of the campsite, a bare-chested guy wearing blue sweat pants and flip flops. Though he plays an important part in the story, he is not referred to in the title, which, besides the two human beings, refers to the anonymous, not clearly defined, antagonist, "tjuven," the thief.

The sociologist and philosopher Zygmunt Bauman uses the tourist as a metaphor to illustrate the condition of postmodern life. The tourist, according to Bauman, moves through spaces that other people inhabit. Bauman describes the current state of modern society as a campsite open for everyone who has a tent or caravan and enough money to pay the rent: "Guests come and go, none taking much interest in how the site is run, providing that they have been allocated a plot big enough" (Bauman $2001,104)$. Nobody demands anything from the site manager except to be "left alone and not interfered with" (Bauman 2001, 105). Perhaps Nordic campsites differ in this respect, but at least campers seem to spend a lot of time together and even make friends in this modern kind of heterotopia, borrowing Foucault's concept of a momentarily realized utopia (Foucault 1984). Furthermore, the campsite could be regarded as a spatial manifestation of the modern distinction between work time and leisure time (Bjurström 2011). It is a piece of cultivated, commercialized nature where people spend a certain time away from their ordinary lives- that is, if they are tourists like Boris and Sonja and not permanent campers.

The plot is simple: Things are disappearing at the campsite and Sonja, Boris, and Björnen are searching for them. It is possible even for a toddler to figure out from the pictures who most likely is the thief, though it is not commented on in the text and one cannot be completely sure. Soon Sonja suspects that the things have been stolen. After she declares this, the characters start looking for a thief rather than for the lost items. A canine 
character called Schäfer (i.e., German shepherd) puts up a poster reading "AKTA ER FÖR TJUVEN" ("BEWARE OF THE THIEF") (Lindström 2007, spread 5). However, the poster contains a picture of himself. Despite his name, this dog, judging from the visual information, is clearly not a German shepherd but most likely a bulldog. This is only one example of how the written and visual texts clash, creating an iconotext that employs counterpoint - to apply Nikolajeva's categories of text/picture relations. Counterpoint means that the words and images question each other in a creative way (Nikolajeva 2000). In this case, the presentation of the dog mocks the idea of an alignment between name and identity. Besides, German shepherds are common police dogs, and this character acts like a private investigator rather than a police officer (or a police dog).

The written presentation completes the visual one by reflecting the part of the text that cannot be discerned in the picture: "Vänd Er med förtroende till Mej om Ni ser något som är borta" ("Turn confidently to Me if you see something that is gone") (Lindström 2007, spread 5).

This is doubly ironic. Intertextually, the poster resembles a typical wanted poster, which usually contains a picture of the suspected criminal. However, as the reader is later informed, the self-appointed detective and the criminal turn out to be one and the same. Furthermore, philosophically, one may ask oneself whether something that is "gone" can actually be seen. This is not meant as linguistic nitpicking, but points toward a general existentialist theme in Lindström's writing: things and people disappear, despite the characters' vain struggles to maintain control.

The traces of suspected crimes disrupt the campsite as a place of temporary harmonious coexistence. Fear is growing, and everyone starts suspecting each another. Soon the police are called in. A male human character arrives, with gray hair, jacket, glasses, and a magnifying glass, recalling a stereotypical detective. He starts, though seemingly not very wholeheartedly, searching for the thief. The character is portrayed with typical detective attributes. The story contains a fair amount of irony targeting the detective genre. The adult reader might also find somewhat ironic the comments indirectly referring to what sociologists call a "risk society," that is, "a society preoccupied with the future (and also with safety), which generates the notion of risk" (Giddens and Pierson 1998, 209), or put another way, a "community of anxiety" (Beck 1992, 50). Ironic references to this theme can be found on the spread depicting how Björnen locks a strongbox locker in a bigger strongbox (Fig. 4.2). 


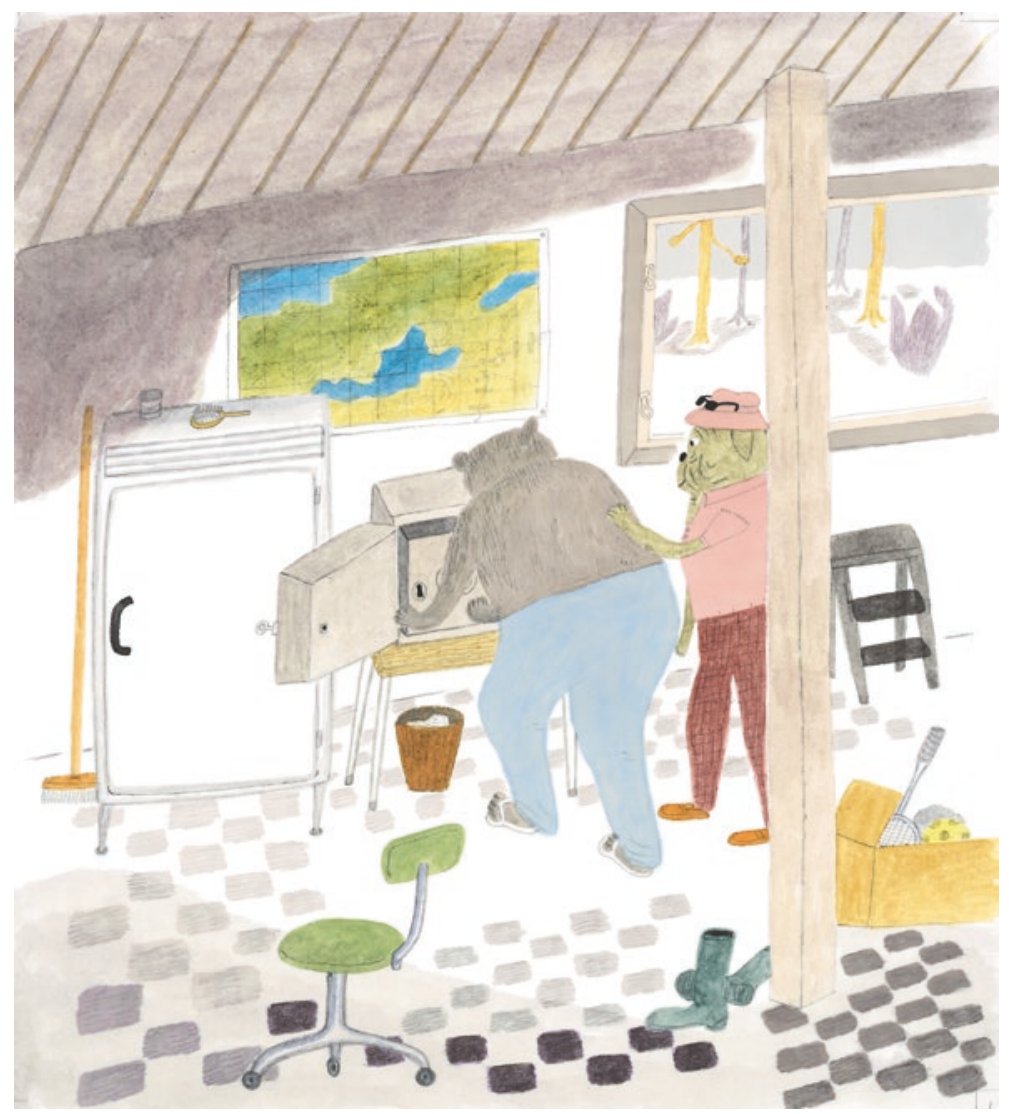

Fig. 4.2 Eva Lindström's illustration in Sonja, Boris och tjuven (2007)

Björnen reckons that Schäfer will guard the place, but things still keep on disappearing. Soon even Schäfer vanishes.

The fact that three sandwiches disappear when Björnen has his back turned in the camping café is noted as peculiar by the narrator. From the picture of the café interior, however, one can tell that the mouth of the dog standing in front of the table where the sandwich was seems crammed full. By means of such an expanded text-picture relationship, to use Nikolajeva's terminology, the reader gains more information than the mere text reader. Significant clues as to the detective mystery are to be found in the pictures (Nikolajeva 2000, 22). 
Sara Ahmed claims that fear does something: "it re-establishes distance between bodies whose difference is read off the surface" (Ahmed 2004, 63). Ahmed discusses fear from a spatial political point of view, recalling that those who in fact have the least reason to fear crime often tend to fear it the most. According to Ahmed, this has to do with the fear of openness itself, a fear of "spaces where bodies and worlds meet and leak into each another" (Ahmed 2004, 69). This reasoning, I would argue, could be connected to Massey's concept of throwntogetherness, a notion of space as performative and effecting or interplaying with social relations. At the campsite in Lindström's book, characters meet with others and the thefts mean that everyone gets more involved with one another, participating in the same project of finding the thief. Simultaneously, however, suspicion grows, disrupting the happy communion presented on the first pages.

In Sonja, Boris och tjuven differences between species are emphasized, as the human police detective takes charge, outmaneuvering Björnen, who owns the campsite, and thus wields economic power. The threat gradually escalates, and the next day it is discovered that there has been a burglar in the café: the strongboxes have been stolen from the office and the whole area is a mess, with broken items and footprints everywhere. The thief's presence has been made visible by these traces. Boris becomes a suspect. His footprints cause the detective to perform a speech act, hailing Boris as a suspect subject: "Du där! (...) Jag får be dig följa med. I lagens namn" ("Hey you! ... Follow me! In the name of the law") (Lindström 2007, spread 8). Despite Sonja's protests, the police take Boris to the police station. This passage could be used as an illustration of interpellation in the sense the French philosopher Louis Althusser uses the term. Althusser even uses a similar, often quoted, example of a police hailing a suspect to explain the ideological process of interpellation (Althusser 2014).

A striking feature of the visual presentation of the campsite is that almost all the doors are ajar, as are the windows and tents, blurring the boundary between inside and outside, mine and yours. This conveys an open, welcoming attitude, connoting community rather than individualism, comfort rather than security. This positive presentation of place is soon juxtaposed, however, to a spread depicting the hearing of Boris and Sonja. Behind the well-lit table where the hearing takes place, there is a door with a huge lock. The right-hand part of the spread shows the building from the outside, with closed doors. The right page depicts the outdoor environment and contains no humans. The page is completely gray, except for two trees in different shades of yellow. There are sharp 
angles everywhere, no messiness but emptiness. The bicycle parking lots contains no bikes, the doors are locked. The only living being present on this part of the spread is a profile looking like Boris that can be seen through a window.

Then we are back at the campsite. The detective has cordoned off the scene of the crime. The theatrical dimension characterizing the book becomes even more profound in this picture of two people watching the detective while he performs his investigation.

In the small community depicted, the thefts cause living beings of different species to come together in their quest for the thief. Sonja does not help her partner Boris when he needs her testimony not to be arrested; instead, she says that she was asleep when the burglary took place, so she cannot provide an alibi. Later, though, she finds an indication that Schäfer and not Boris is guilty, and calls the police. But, as mentioned above, Schäfer has disappeared.

Eventually, a common space is established on the ground between the separate tents at the campsite. Boris has been set free and has returned to the campsite. The incidents seem to have brought the characters closer together. Sonja, Boris, and the detective are sitting down on the ground, remarkably relaxed and content judging from the picture. Björnen stands at the back, holding a tray of buns. None of them any longer seems interested in solving the case; instead the dialogue is about Boris's experiences in the cell. However, the final words paradoxically claim that detective action is still going on, though less intensely: "Utredningen går långsamt framåt. Ännu har ingen tjuv åkt fast" ("The investigation is slowly proceeding. Yet no thief has been caught") (Lindström 2007, 12).

This is only one example in which, to use Nikolajeva's terminology, elements of counterpoint escalate into an ambivalent text-picture relationship. The clash between written and visual information produces a certain amount of uncertainty, and there is no corrective to lean on (Nikolajeva $2000,22)$. This collision is related to the mild kind of irony characterizing the picturebook or even Lindström's production in general.

The ending contains almost classical ingredients, recalling that of Tove Jansson's 1952 picturebook Hur gick det sen? ("What happened after?"), published in English as The Book about Moomin, Mymble and Little My. In Jansson's book, on the last spread everyone is sitting on the ground, drinking lemonade. "The adventure is over," Druker commented on this ending in her dissertation on pictures in this and other modern picturebooks, including Jansson's (Druker 2008, 95). What is the case, however, 
in Lindström's book? If Boris is to be regarded as the protagonist, he has clearly completed an adventure, first being forced from his temporary home, put in a cell, and eventually returned to the campsite. However, against the backdrop of Massey's concept of throwntogetherness and her reasoning on place as an event, it is possible to submit that the camping site including its inhabitants is the most profound protagonist. Not only Boris, but the place has been transformed, from the first presentation of a casual community characterized by openness and diversity to a micro version of the risk society in which suspicion grows and social relations crack. Finally, it has once again become a place of relaxed social intercourse. As discussed above, the story mocks the idea of a proper (detective) plot as well as heroic individualism.

Even though the detective riddle remains unsolved at the end, the most prominent characters except for Schäfer are finally gathered, having coffee and cake. Actually, the thefts do not seem to bother them anymore. The story ends by showing a content little community, now also including the nonresidential police detective. Sharing a meal outdoors is part of the happy ending.

Burglaries take place, but the important thing seems to be what one makes of that. The voluntary, positive situation of throwntogetherness at the campsite eventually triumphs over the fear of crime. According to Massey, this term refers to an "event of place in part in the simple sense of the coming together of the previously unrelated, a constellation of processes rather than a thing" (Massey 2005, 141). The final spread depicts a new appropriation of place, giving it new meaning. The place once again functions as an arena of communion where both old and new inhabitants are eating cake together.

However, even in this almost utopian local community, power relations can be discerned, though they are not commented on. Regarding gender, it is notable that the suspect, the actual (or most likely) thief, and the police detective are all male. Furthermore, the written text tells us that Sonja has made the cake, while the male animal character Björnen simply defrosted some buns in the microwave oven. Yet they both in different ways help reclaim the campsite as a place for enjoyment and community, including newcomers. 


\section{Different Flats, Same House: Where You Live AND WhO You Are}

Emma Adbåge is a well-established writer and a frequent illustrator of picturebooks. In Tilly som trodde att ... ("Tilly who thought that ..."), the pictures were drawn by Adbåge and the text was written by Eva Staaf, here debuting as an author. If Sonja, Boris och tjuven mocks the traditional detective plot, this genre lacks a plot. It is based on various settings and various social relations, or more precisely different kinds of homes connected by a narrator focalizing on the young protagonists Tilly and Tage. The significance of class regarding social environments as well as social relations is suggested by the visual presentation of each flat and its inhabitants, but it is not verbally commented on.

The front cover presents a picture of an apartment building from the outside. On the back cover of the book, the apartment building is depicted from another angle, showing balconies and a front door through which a person is about to pass. A dog is peeing on the messy ground. Through the windows, people of different ages can be seen. The first spread seems to show the view from the apartment where Tilly and Tage live, an urban landscape of colorful apartment buildings, a playground, a school, and a swimming center. The right-hand page shows Tilly's room, where she and her friend Tage are sitting on the bed:

De bor i ett hus de är vana att bo för de har bott där sen de föddes.

De vet inte exakt hur det är att bo någon annanstans (...)

Tilly och Tage vet inte exakt hur det skulle kunna vara att vara någon annan.

Har man tur, kan man kanske få veta det. (Staaf 2014, spread 1)

They live in a house where they are used to living because they have lived there since they were born.

They don't know exactly how it is to live somewhere else (...)

Tilly and Tage don't know exactly what it would be like to be someone else.

If you're lucky, you might find out. (Trans. KH)

The written text makes spatial aspects central to the presentation of characters and social relations. The narration also has a spatial structure, following Tilly's movements through different apartments, outside, and to the swimming center. Each home is presented from Tilly's and Tage's points of view, particularly in their dialogues. They eventually find out that 
not everyone has a room of their own and that families come in very different forms. Several single parents do occur, though there are no samesex couples. The characters are strikingly white, considering the diversity regarding other aspects. On the other hand, all characters except from the homeless man live in the same house.

The home of Tilly's friend Loppan is depicted as a place where many things are allowed, where one can remove the cushions from the couch or play with real biscuits and apples. The picture shows Loppan's mother, wearing sweatpants revealing her stomach with the waistband of her underpants visible. She stands at a desk, drinking tea while the kids play in the very messy apartment. The floor is full of stuff and through the door one can see a bedroom with an unmade bed.

The next spread depicts Tage's home. In contrast, this picture show a perfectly organized kitchen with the blinds pulled down. On a chair sits a neatly dressed woman with glasses, while Tilly and Tage sit on the sofa looking at each other in a worried way: "Tages mamma säger att allt inte är roligt här i livet. Att det är något man lär sig när man blir större" ("Tage's mum says that not everything in life is fun. That is something that one learns as one gets older") (Staaf 2014, spread 3). The anxiety is manifested in several ways in the darkened room, and the written text tells of the ticking clocks. The text as well as the visual depiction of the setting emphasizes the mother's negative stance toward life. Or, to put it another way, the material order reflects and emphasizes the depressive disorder.

The next spread depicts Tilly's meeting with a homeless man sitting in the street and begging for money. She asks her mum to give him money, though she only brought her credit card. When the mother explains to Tilly that it is a card loaded with money, Tilly thinks it would be even better to give it to the beggar. The mother, though, just continues walking.

The scene with the beggar is re-enacted later on, as Tilly, on her way home, returns to the spot where she first saw the homeless man. This time, Tilly's mother is more proactive in avoiding him. From Tilly's perspective, the written text informs the reader that the mother seems to be having a problem with her shoelaces. The visual presentation shows the mother apparently tying her shoelaces somewhat away from Tilly and the beggar. In the following dialogue with Tage, the two friends talk about why people do not help one another, though even small children know that one ought to. The question goes unanswered, and Tage describes it as a good but hard one.

At the swimming center, another manifestation of inequality is brought to the fore. One of the children, Boris, has not brought a swimsuit or towel, and the written text says that he never has. This surprises Tilly, who 
thought that all parents would read the messages from the teacher. On the left side of the spread depicting the swimming pool, Boris sits to the left of Tilly by the pool, not part of the happy fellowship of bathing kids. Tilly is wearing a towel, and has just left the others for a while. The right side of the spread depicts the dressing room, in which Boris sits crouched on a bench, looking at the others. In this picture, he is spatially marginalized because he does not have a bathing suit. However, the written text might indicate, at least for the adult reader, that this is only one expression of a more thorough marginalization related to his family situation. However, the swimming teacher overlooks the pattern that is obvious to Tilly and simply tells Boris to remember his bathing suit next time.

Later, Tilly and Tage show up at Sonja's place, a friend who, according to the narrator as well as to Sonja herself, has everything. Tilly finds out that no parents are at home. Sonja claims that she has no mother and that her father is usually away traveling, so her grandmother takes care of her. Tilly, the written texts informs, had so far supposed that every child has a mum and a dad. Obviously, she is unaware that there are several kinds of family constellations.

In some homes, living together does not work properly, though this does not bother the competent, young protagonists who adapt themselves to any circumstances. The spread about Peppe's place shows a very dirty bathroom. Peppe's father never cleans and the household has run out of toilet paper, so Tilly wipes herself with a dirty sock from the laundry. In the picture, Tage and Tilly are happily playing in the dirty bathtub. In the next spread, they have entered Freddie's home where lots of different people mix: Freddie's family is like "ett knippe gräs" ("a bundle of grass") in comparison with Tilly's explicit idea of a family as a constellation with "en början och ett slut" ("a beginning and an end") (Staaf 2014, spread 11).

The differences between homes surprise the young protagonists, but except for the situation of the beggar, they are not understood as manifestations of inequality. Like Milja in Milja och grannarna, Tilly notices the differences between people while not really valuing or categorizing them, though Tilly and Tage do reflect on these differences.

From Tilly's and Tage's point of view, the reader 'enters' many different homes and meets their different inhabitants. One by one, Tilly's prejudices are challenged, especially regarding adults who do not behave "properly" or exactly the way she expected. Lack of care of one's home is highlighted as a sign not only of otherness, but-at least for the adult reader-as a sign of low socioeconomic status and/or dysfunction. 
Mimmi lives in an extremely messy apartment. In the picture, we find that her tattooed mother is smoking below the kitchen fan, wearing a thong partly visible above her jeans. On the table, there is an emptied piggy bank and an ashtray. The socioeconomic status of this family is stressed by the written description of a lack of food: no fruit, no sweets, no cookies, no milk (Fig. 4.3).

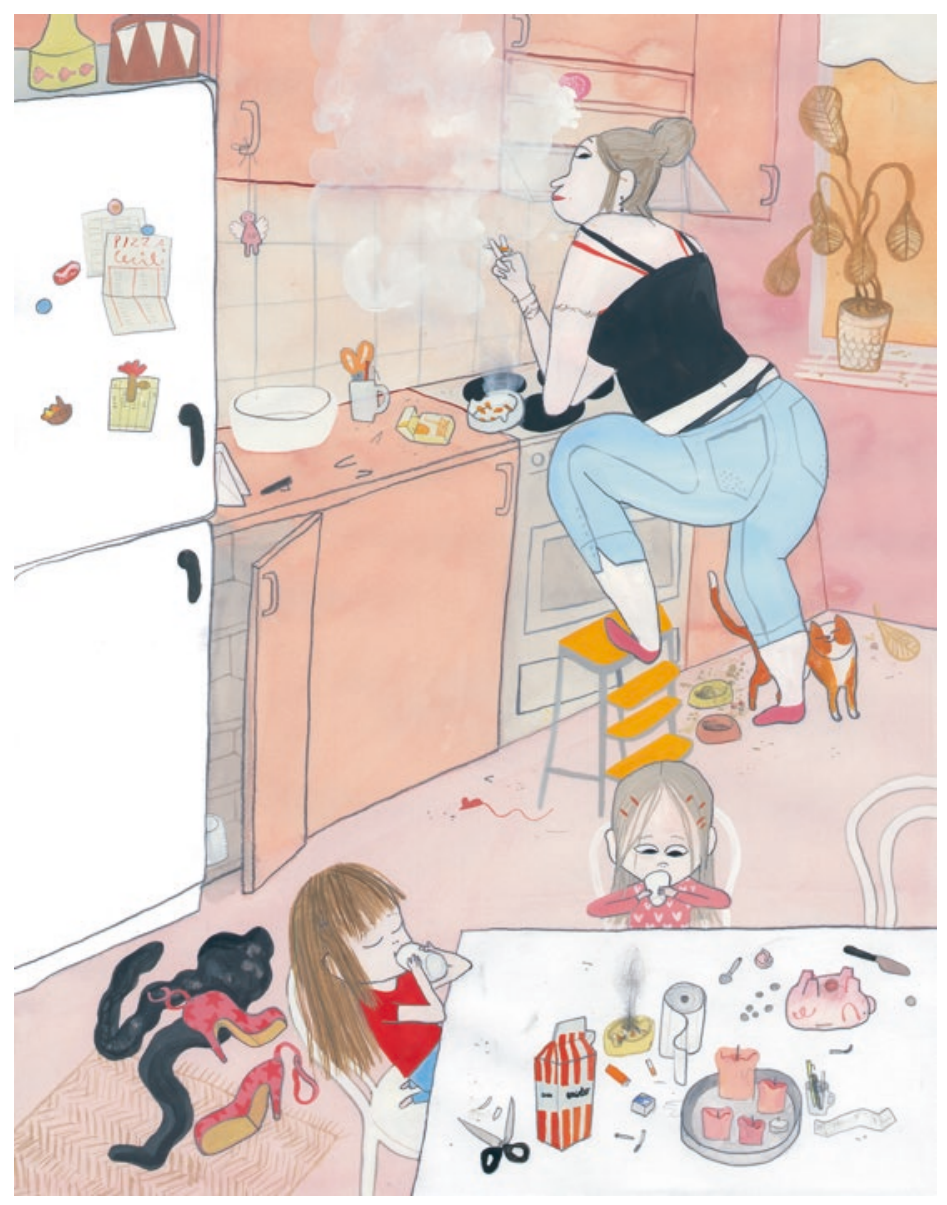

Fig. 4.3 Emma Adbåge's illustration in Tilly som trodde att... (2014), by Eva Staaf and Emma Adbåge 
In the utopian final spread, Tilly and Tage go on an excursion with their preschool, visiting the beggar's spot on the street alongside a building. In the visual presentation, all the children and their preschool teachers have gathered round the homeless man and share their food with him. The written text informs us that the children give him all they have and that the event becomes like a party. In the picture, most people are smiling. The beggar and Tilly are sitting side by side, looking at each other.

In this spread, people, as illustrated in the visual and written narrative, enact a temporary communion on the street. Following Lefebvre's reasoning, this collective appropriation of a public place, in this case by the preschool group, could be regarded as the transformation of dominating space into lived space. The place might in the end be comprehended as a carnivalesque redomination of a certain spot, earlier appropriated by the homeless person and now turned into a happy community. However, even when the socially most marginalized and exposed character is the center of others' attention, he does not utter a word and remains completely anonymous. As the preschoolers enter his non-home and turn it into a picnic spot, he is simultaneously given the function of being a peculiar point of interest, an excursion destination. Tillys final reflection is neither about him nor about inequality. The verbal text focus her assumption about adult food preferences, that now is challenged. This leads to the conclusion that, fortunately, one cannot know everything.

Eventually, Tage and Tilly as well as the reader have gained some insight into their neighbors' various living conditions. However, they are not presented like the traditional protagonist moving away from home, experiencing an adventure and then returning home again. This is rather an episodic picturebook in which the title character and her friend function like commentators reflecting on the episodes and settings presented. The eventual 'home coming' takes place out in the street, where the social relations and the place is altered. The formerly most marginalized person has now become the center of the event.

\section{Reproducing Places: Final Reflections AND CONCLUSIONS}

The literary examples analyzed above end, as mentioned, with characters coming together, sharing a meal on the ground. In Lindström's Sonja, Boris och tjuven, the burglaries have an obvious effect on the environment and on social relations that are transforming in a direction toward what sociologists would call a risk society. However, in the end the story takes another turn, replacing the former increasing anxiety with a calm reunion. 
In the last spread, Sonja and Boris are sitting down together along with the detective while Björnen offers them buns. No one seems to be at all worried even though the case has not been solved. The only one missing is the suspected burglar, Schäfer, who has mysteriously disappeared, similar to the way things mysteriously started to disappear at the outset. However, ultimately no one seems to be bothered either about him or the things lost. It is not stated whether things are still disappearing, or whether it is the anxiety that has vanished. Instead, a relaxed community is highlighted. The characters are depicted as enjoying one another's company.

This ending recalls the final spread in Tilly som trodde att...: the two protagonists are gathered outdoors with the preschool group, not at a campsite but out on the street next to the man who used to ask for money. They are having a picnic, sharing their food with the beggar.

In all three examples that have been analyzed, the stories end by presenting more or less temporary gatherings in which the characters are having a meal together outside. This is where the adventures end, not back in the protagonist's individual homes but in outdoor communions at collectively appropriated places, in public or in semi-public areas: on a campsite, in the street, or in the yard.

In all these examples, eventually humans-and in two cases nonhumans as well-both children and adults from different backgrounds come together outside on the ground, if only momentarily. No one has returned to his or her private habitation. Yet a common home is established within the communities presented.

By applying Massey's theories of place and the concept of throwntogetherness, it becomes clear that the presentation of place in these picturebooks cannot be fully comprehended independent of the presentation of social relations, or the other way round. The analyzed works end on an almost utopian note, depicting places from earlier in the books in a new or renewed light, and consistently positively contested. However, these places have in various respects been changed just as the social relations have been. Sonja, Boris och tjuven eventually re-establishes the laidback community of the camping site in a somewhat new constellation. In Milja och grannarna, it is Milja's imaginary neighbor kinship that is realized. Finally, in Tilly som trodde att ..., a communion including a preschool group and a homeless man takes place out in the street, or at least the center-periphery relations are shifted. In this sense, the presentation of place in Massey's terms, including characters and their social relations, form a collective protagonist. In all three cases, the characters eventually share a meal out- 
doors. Hence, the presentations of places and social relations are intertwined, mutually conditioned, and transformed. Eventually, individualistic isolation and (adult) suspicion toward one's neighbor is overcome on public or semi-public ground.

\section{Note}

1. There are other contemporary examples that could have been added in this study. The motif of neighbors, especially in apartment blocks, has become increasingly common during the last decade, for example: Hela huset by Anna Bengtsson (2007; "All of the house"); Stig tittar ut by Ann-Christine Magnusson (2011; "Stig peeps out"); Ett hus med många dörrar by Sanna Juhlin (2013; “A house with several doors"); Huset som vaknade by Martin Widmark (2017; "The house that woke up"); Kompisen $i$ hissen by Minette Lidberg (2017; "The friend in the elevator"); Nyckelknipan [The title is difficult to translate since it is a wordplay, fusing the words for "bunch of keys" with "trouble"] by Sanna Mander (2017); and I huset där jag bor by Lena Sjöberg (2018; "In the house where I live"). They relate in different ways to the home-adventure-home structure, since they present different kinds of denouements. The covers of the books by Bengtsson, Juhlin, Lidberg, Mander, Sjöberg as well as the one by Staaf analyzed in the chapter show blocks of apartments, thereby visually emphasizing the main motif of the books that in various ways thematize social relations in a late modern society. My selection for the article aims to present a broad spectrum of narration as well as various forms of living together, while still relating to the home-away-home pattern in somewhat similar ways in order to make a comparative analysis more fruitful.

\section{REFERENCES}

Ahmed, Sara. 2004. The Cultural Politics of Emotion. New York: Routledge. Althusser, Louis. 2014 [1969-1970]. On the Reproduction of Capitalism: Ideology and Ideological State Apparatuses. London: Verso.

Bauman, Zygmunt. 2000. Liquid Modernity. Cambridge: Polity. . 2001. The Individualized Society. Cambridge: Polity Press.

Beck, Ulrich. 1992. Risk Society: Towards a New Modernity. London: Sage.

Beckett, Sandra. 2002. Crossover Picturebooks: A Genre for All Ages. New York: Routledge.

Bengtsson, Anna. 2007. Hela huset. Stockholm: Alfabeta.

Bjurström, Erling. 2011. Fritidens rum: Topografiska perspektiv på ungdomars fritidssocialisation och ungdomspolitiken. Stockholm: Ungdomsstyrelsen. 
Brown, Wendy. 1995. States of Injury: Power and Freedom in Late Modernity. Princeton: Princeton University Press.

Druker, Elina. 2008. Modernismens bilder: den moderna bilderboken $i$ Norden. Diss. Stockholm: Stockholms universitet.

— 2011. På jakt efter de ting som flytt. Den främmandegjorda vardagen i Eva Lindströms böcker. In Barnlitteraturanalyser, ed. Maria Andersson and Elina Druker, 41-54. Lund: Studentlitteratur.

Foucault, Michael. 1984 [1967]. Of Other Spaces: On Utopias and Heterotopias. Translated by Jay Miskowiec. http://web.mit.edu/allanmc/www/foucaultl.pdf.

Giddens, Anthony, and Christopher Pierson. 1998. Conversations with Anthony Giddens: Making Sense of Modernity. Cambridge: Polity Press.

Hallberg, Kristina. 1982. På jakt efter de ting som flytt. Den främmandegjorda vardagen i Eva Lindströms böcker. Litteraturvetenskapen och bilderboksforskningen. Tidskrift för litteraturvetenskap 3-4: 163-168.

Hermansson, Kristina, and Anna Nordenstam. 2017. A New Niche in Children's Literature. Norm-Crit Picture Books in Sweden. LIR. Journal: Performing the Child. Power and Politics in Children's Literature and Culture 9: 97-120.

Jansson, Tove. 1952. Hur gick det sen?(Boken om Mymlan, Mumintrollet och lilla My). Stockholm: Geber.

Juhlin, Sanna. 2013. Ett hus med många dörrar. Färjestaden: Vombat.

Lefebvre, Henri. 1991. The Production of Space. Oxford: Basil Blackwell.

Lidberg, Minette. 2017. Kompisen i hissen. Bromma: Opal.

Lindström, Eva. 2007. Sonja, Boris och tjuven. Stockholm: Alfabeta.

- 2008. I skogen. Stockholm: Alfabeta.

Magnusson, Ann-Christine. 2011. Stig tittar ut. Bromma: Opal.

Mander, Sanna. 2017. Nyckelknipan. Helsingfors: Schildts \& Söderströms.

Massey, Doreen. 2005. For Space. London: Sage.

Nikolajeva, Maria. 2000. Bilderbokens pusselbitar. Lund: Studentlitteratur.

- 2004. Barnbokens byggklossar. Lund: Studentlitteratur.

Nikolajeva, Maria, and Carole Scott. 2001. How Picturebooks Work. New York: Garland.

Nodelman, Perry. 2008. The Hidden Adult: Defining Children's Literature. Baltimore: Johns Hopkins University Press.

Rhedin, Ulla. 2013. Kaos och ordning. Att berätta ur barnets perspektiv och våga möta barndomens mörker. In En fanfar för bilderboken! ed. Ulla Rhedin et al., 37-63. Stockholm: Alfabeta.

Rönnlund, Maria, and Aina Tollefsen. 2016. Rum: sambällsvetenskapliga perspektiv. Stockholm: Liber.

Sandelin, Annika. 2006. Milja och grannarna. Helsingfors: Söderström.

Sjöberg, Lena. 2018. I huset där jag bor. Stockholm: Rabén \& Sjögren.

Staaf, Eva. 2014. Tilly som trodde att .... Stockholm: Rabén \& Sjögren.

Widmark, Martin. 2017. Huset som vaknade. Stockholm: Bonnier Carlsen. 
Open Access This chapter is licensed under the terms of the Creative Commons Attribution 4.0 International License (http://creativecommons.org/licenses/ by $/ 4.0 /)$, which permits use, sharing, adaptation, distribution and reproduction in any medium or format, as long as you give appropriate credit to the original author(s) and the source, provide a link to the Creative Commons licence and indicate if changes were made.

The images or other third party material in this chapter are included in the chapter's Creative Commons licence, unless indicated otherwise in a credit line to the material. If material is not included in the chapter's Creative Commons licence and your intended use is not permitted by statutory regulation or exceeds the permitted use, you will need to obtain permission directly from the copyright holder.

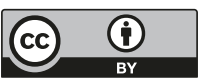

